gene16661-16660-16661 in B2 only

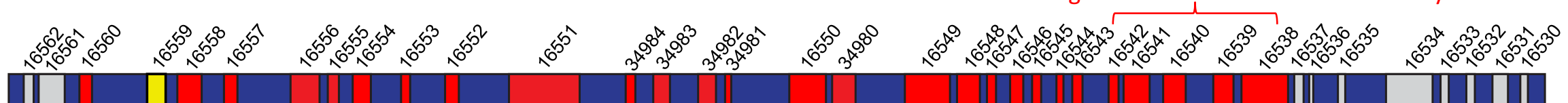

probe 4

BAC040

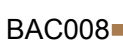

BAC008

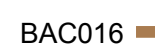

BAc0so

BAC069
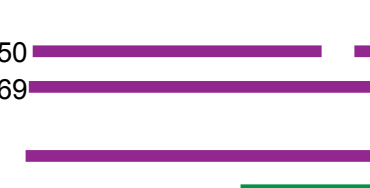
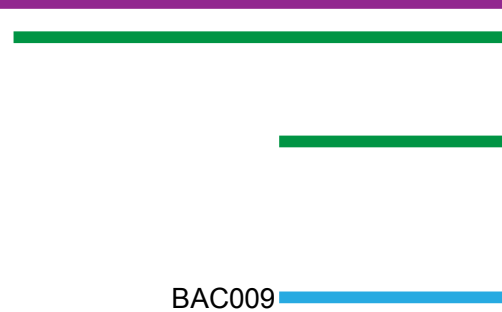

Bi (7/9)

BAC031

BAC044

$$
\text { BAC009 }
$$

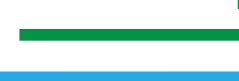

Iprobe 3 Iprobe 2

Z/B2-r (6)

Z/B2-r (8)
Iprobe 1

BAC033

BAC038

BAC045

BAC010

BAC024

\section{B1 (3)}

B1 (4)

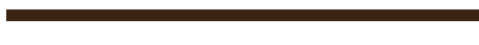

Av (5)

BAC052

$A v(2)^{\text {BAC018 }}$

BAC029 